\title{
Optimasi Aturan Asosiasi Multidimensi menggunakan Algoritme Genetika untuk Klasifikasi Kemunculan Titik Panas
}

\author{
Multidimension Association Rule Optimization using Genetic \\ Algorithm for hotspot occurrence Classification
}

NIA KURNIATI $^{*}$, IMAS SUKAESIH SITANGGANG ${ }^{1}$, IRMAN HERMADI ${ }^{1}$

\begin{abstract}
Abstrak
Penelitian ini menggunakan algoritme genetika untuk mengoptimalkan pembentukan aturan asosiasi yang dihasilkan dari algoritme apriori. Algoritme apriori diterapkan pada dataset kebakaran hutan dengan daerah penelitian di wilayah Rokan Hilir provinsi Riau. Aturan asosiasi diklasifikasi menggunakan algoritme CPAR (Classification Based on Predictive Association Rules) untuk mengetahui karakteristik wilayah yang berpotensi munculnya titik panas. Optimasi dalam algoritme genetika dilakukan melalui tahapan: skema pengkodean, evaluasi fitness, seleksi, pindah silang, mutasi. Hasil yang diperoleh dari penelitian ini ialah jumlah aturan dapat dikurangi. Jumlah aturan yang dihasilkan yaitu sebanyak 121 aturan pada generasi ke-300 hingga mencapai 108 aturan pada generasi ke-50. Hasil klasifikasi menunjukkan bahwa daerah yang berpotensi timbulnya titik panas yang terdapat pada generasi ke-50 ditemukan pada daerah yang memiliki curah hujan lebih besar dari atau sama dengan $3 \mathrm{~mm}$ per hari dan yang memiliki temperatur pada interval 297 Kelvin hingga 298 Kelvin dengan laplace akurasi sebesar 0.76. Pada generasi 150 ditemukan daerah yang memiliki temperatur yaitu pada interval 297 Kelvin hingga 298 Kelvin dengan laplace akurasi sebesar 0.57. Pada generasi 300 ditemukan pada daerah yang memiliki kecepatan angin yaitu pada interval $1 \mathrm{~m} \mathrm{~s}^{-1}$ hingga $2 \mathrm{~m} \mathrm{~s}^{-1}$ dengan laplace akurasi sebesar 0.70 .
\end{abstract}

Kata kunci: algortime apriori, algoritme CPAR, algoritme genetika, aturan asosiasi multidimensi, titik panas.

\begin{abstract}
This study used genetic algorithm to optimize association rules generated using the Apriori algorithm. Apriori algorithm was applied to forest fires multidimensional dataset with the study area in Rokan Hilir Riau province. Association rules were used to classify hotspot occurrence using the CPAR (Prediction Classification based on Association Rule) algorithm to determine the characteristics of areas are potential of hotspot occurence.Optimization in genetic algorithms was done through these stages: encoding scheme, fitness evaluation, selection (roulette wheel), crossovers (one point crossover), and mutation. The results showed the proposed method successfully reduced the number of association rules. The number of rules generated as many as 121 in the generation of 300 to reach 108 rule in the 50th generation. Classification results show that the area has the potential emergence of hotspots were found on the generation of 50, found in areas where rainfall is greater than or equal to $3 \mathrm{~mm}$ per day and which has a temperature in the interval 297 Kelvin to 298 Kelvin by Laplace accuracy of 0.76. In the generation of 150, we found the area that have a temperature in the interval 297 Kelvin to 298 Kelvin by Laplace accuracy of 0.57. In the generation of 300, we found the area that have a wind speeds that is intervals of $1 \mathrm{~m} \mathrm{~s}^{-1}$ up to $2 \mathrm{~m} \mathrm{~s}^{-1}$ with Laplace accuracy of 0.70 .
\end{abstract}

Keywords : Apriori algorithm, association rule multidimension, CPAR algorithm, genetic algorithm, hotspot.

\section{PENDAHULUAN}

Kebakaran hutan dan lahan menjadi suatu permasalahan yang serius di Indonesia. Kejadian kebakaran hutan di Indonesia meningkat dari tahun ke tahun. Kabupaten Rokan Hilir adalah salah satu wilayah yang sering mengalami kebakaran hutan dan lahan di Riau. Pada

\footnotetext{
${ }^{1}$ Departemen Ilmu Komputer, Fakultas Matematika dan Ilmu Pengetahuan Alam, Institut Pertanian Bogor, Bogor

*Penulis korespondensi: Tel/Faks: 085242850385; Surel: nhia.imb@gmail.com
} 
bulan Februari dan Maret tahun 2014 kebakaran yang terjadi telah menyebabkan kerugian hingga 20 triliun rupiah (Nugroho 2014). Menurut Syaufina (2008) kebakaran pada umumnya disebabkan oleh faktor manusia dan sebagian kecil karena faktor alam. Indikasi kebakaran hutan dan lahan dapat diketahui melalui titik panas yang terdeteksi di suatu lokasi tertentu pada saat tertentu (Syaufina 2008). Salah satu yang dapat diterapkan dalam upaya pencegahan kebakaran hutan ialah mengetahui karakteristik wilayah terjadinya titik panas dengan menggunakan teknik data mining. Data mining memiliki kemampuan untuk menemukan pola yang sering muncul di dalam dataset salah satunya yaitu menerapkan penambangan aturan asosiasi. Menurut Han et al. (2012) aturan asosiasi adalah pengetahuan untuk mengetahui keterkaitan dan bobot kepentingan objek yang satu dengan yang lainnya.

Aturan asosiasi multidimensi merupakan pengetahuan baru yang mulai banyak dikembangkan. Studi oleh Sitanggang (2013) menerapkan teknik data mining yaitu penambangan aturan asosiasi menggunakan algoritme apriori. Dengan menggunakan minimum support sebesar $10 \%$ dan minimum confidence sebesar $80 \%$ diperoleh sejumlah aturan untuk mengetahui faktor-faktor yang memengaruhi terjadinya titik panas sebagai indikator terjadinya peristiwa kebakaran hutan. Menurut Han et al. (2012) aturan asosiasi yang bersifat multidimensional disebut dengan high dimensional pattern. Aturan asosiasi spasial multidimensi cenderung memiliki banyak kombinasi yaitu lebih kompleks dan lebih bervariasi dari pada non-spasial. Aturan ini tidak hanya melibatkan satu predikat tapi juga dapat terdiri dari dua predikat atau lebih. Menurut Saggar et al. (2004) Penambangan aturan asosiasi menghasilkan kompleksitas dalam aturan yang bersifat algoritmik. Salah satu kompleksitas yang ditimbulkan yaitu jumlah aturan tumbuh secara eksponensial berdasarkan jumlah item. Kompleksitas ini dapat ditangani dengan memangkas ruang pencarian dan menemukan aturan yang berkualitas. Kompleksitas yang ditemukan ini diperlukan suatu algoritme untuk menemukan kemungkinan-kemungkinan dalam memperoleh solusi yang optimal. Salah satu solusi optimal ialah menerapkan metode algoritme genetika.

Algoritme genetika merupakan metode penyelesaian solusi dari berbagai macam jenis permasalahan. Salah satu kasus permasalahan yang dapat diterapkan ialah yang berkaitan mengenai penambangan aturan asosiasi. Hsu et al. (2003) pertama kali menggabungkan algoritme aturan asosiasi dan algoritme genetika dalam melakukan pencarian secara efisien. Ghosh dan Nath (2004) menerapkan algortime genetika dalam mengurangi aturan yang bersifat multiobjektif. Prakash et al. (2011) menghasilkan sejumlah frequent itemset dengan memperhatikan atribut diskrit dan interval dalam proses penemuan aturan dan berhasil mengurangi waktu proses komputasi Du et al. (2009) mengurangi aturan yang berlebihan dan meningkatkan efisiensi pencarian. Saggar et al. (2004) mengoptimalkan kompleksitas aturan yang ditimbulkan dengan memperhatikan atribut negatif. Saxena et al. (2012) mengurangi proses iterasi dalam menghasilkan individu yang terbaik.

Tujuan dari penelitian ini adalah menerapkan algoritme genetika dengan membuat model optimasi pembangkitan aturan asosiasi berbasis apriori untuk mengoptimasi 1080 aturan asosiasi multidimensi yang dihasilkan oleh Sitanggang (2013). Diharapkan jumlah aturan yang dihasilkan lebih sedikit dan mengetahui model aturan yang dihasilkan. Aturan yang diperoleh kemudian dibentuk aturan klasifikasi menggunakan algoritme CPAR (Classification Based on Predictive Association Rules) untuk mengidentifikasi karakteristik wilayah yang berpotensi munculnya titik panas.

\section{METODE}

Penelitian ini mencoba mengurangi aturan asosiasi multidimensi yang telah dihasilkan oleh Sitanggang (2013) dengan menggunakan algoritme genetika. Penelitian ini terdiri atas 3 tahap,yaitu optimasi aturan asosiasi multidimensi menggunakan algoritme genetika, klasifikasi kemunculan titik panas (algoritme CPAR), dan evaluasi aturan. Dalam Goldberg (1989) optimasi dalam Algoritme Genetika dilakukan melalui tahapan : skema pengkodean (encoding), evaluasi fitness, seleksi, pindah silang, dan mutasi.Alur penelitian pada Gambar 1. 


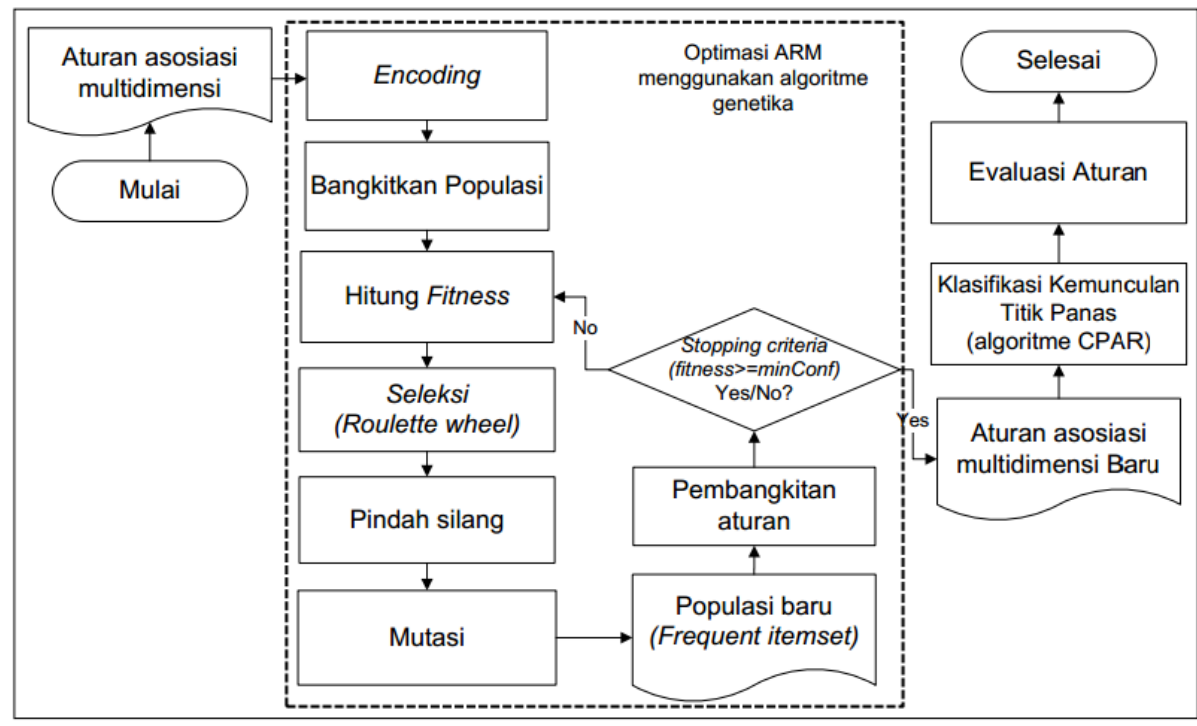

Gambar 5 Alur penelitian untuk optimasi aturan asosiasi menggunakan Algoritme Genetika

\section{Data Lokasi}

Data spasial yang digunakan mengacu pada data penelitian sebelumnya (Sitanggang 2013) yaitu dataset kebakaran hutan wilayah Kabupaten Rokan Hilir provinsi Riau tahun 2008. Data ini meliputi kondisi geografis, ekonomi, sosial dan cuaca. Adapun data dan sumber data yang diperoleh diuraikan pada Tabel 1.

Tabel 1 Data dan sumber data (Sitanggang 2013)

\begin{tabular}{|c|c|c|}
\hline Data & Tahun & Sumber \\
\hline Titik panas & 2008 & $\begin{array}{l}\text { FIRMS MODIS Fire/Titik panas, } \\
\text { NASA/University of Maryland }\end{array}$ \\
\hline $\begin{array}{l}\text { Suhu harian maksimal, curah hujan harian, dan } \\
\text { kecepatan angin }\end{array}$ & 2008 & $\begin{array}{l}\text { Badan Meterologi Klimatologi dan } \\
\text { Geofisika (BMKG) }\end{array}$ \\
\hline Sungai, jalan, dan tutupan lahan & 2008 & $\begin{array}{l}\text { Badan Koordinasi Survey dan Pemetaan } \\
\text { Nasional (BAKOSURTANAL) }\end{array}$ \\
\hline Tipe lahan gambut, kedalaman dan lahan gambut & & Weatland International \\
\hline Sumber pendapatan & & BPS (Badan Pusat Statistik) \\
\hline
\end{tabular}

\section{Optimasi aturan asosiasi multidimensi menggunakan Algoritme Genetika}

Penelitian ini bertujuan untuk mengurangi aturan asosiasi multidimensi yang telah dihasilkan oleh Sitanggang (2013) dengan menggunakan algoritme genetika. Jumlah aturan asosiasi yang diperoleh sebanyak 1080 aturan yang terdiri dari fitur spasial.

\section{Pembangkitan Populasi}

Tahap awal yang dilakukan dalam proses algoritme genetika ialah membangkitkan populasi sebanyak jumlah kromosom. Pada tahap ini Jumlah ukuran populasi yang dibangkitkan ialah sebanyak 1080 kromosom.

\section{Skema pengkodean (Encoding)}

Skema pengkodean dilakukan melalui pendekatan Michigan. Menurut Du et al. (2009) aturan dikodekan sebagai nomor baku. Setiap aturan dikodekan ke dalam kromosom (Gupta dan Sikka 2013). Representasi kromosom dapat dilakukan menggunakan penomoran, pohon, bit, array, daftar atau dalam bentuk lainnya (Indira dan Kanmani 2012). Pengkodean dilakukan disebabkan jumlah string yang cukup panjang dan tidak efisien. Pada tahap ini masing-masing variabel string diterjemahkan berdasarkan ukuran dan jumlah data. Setiap 1 (satu) string membawa 3 digit angka di mana setiap gen ditempatkan berdasarkan urutan masing-masing. Pada Gambar 2 menunjukkan pembentukan kromosom yang dikodekan di mana $A$ adalah antecendent (bagian jika), $B$ adalah consequent (bagian maka). 
Contoh rule ke-78:

\begin{tabular}{|l|c|c|c|}
\hline if Dist_road $<=2.5 \mathrm{~km}, \quad$ Screen_temp $=(297 \mathrm{~K} ; 298 \mathrm{~K}), \quad$ Hotspot_occurence $=$ Yes & then & Precipitation $>=3 m m / d a y$ \\
\hline
\end{tabular}

Gambar 2 Pembentukan kromosom

\section{Evaluasi fitness}

Evaluasi nilai fitness adalah nilai yang menyatakan baik tidaknya suatu solusi (kromosom). Nilai fitness yang paling tinggi menjadi tolak ukur optimal suatu solusi. Semakin optimal nilai fitness yang dihasilkan maka kualitas kromosom yang memenuhi nilai fitness tersebut dinyatakan semakin baik. Menurut Du et al. (2009) support dan confidence merupakan parameter dari nilai fitness. Variabel $a$ dan variabel $b$ merupakan koefisien bobot untuk mengontrol nilai fitness. Koefisien bobot dinyatakan sebagai $0<a \leq 1$ dan $0<b \leq$ 1 di mana $a=0.5$ dan $b=0.5$. Nilai fitness diberikan pada persamaan 1 (Du et al. 2009):

dengan,

$$
\operatorname{fitness}(r)=a \times \sup (r)+b \times \operatorname{conf}(r)
$$

sup : Support dari aturan $r \quad a \quad$ : Koefisien bobot nilai support

conf : Confidence dari aturan $r \quad b \quad$ : Koefisien bobot nilai confidence

\section{Seleksi}

Proses seleksi menggunakan roulette wheel yaitu menyeleksi populasi baru dengan melakukan distribusi probabilitas berdasarkan hasil probabilitas yang terpilih. Kromosom yang terpilih dievaluasi dengan menggunakan nilai fitness kemudian diseleksi untuk dijadikan induk (Goldberg 1989).

\section{Pindah Silang}

Pindah silang (crossover) adalah operator algoritme genetika yang dilakukan pada sepasang kromosom induk untuk menghasilkan dua kromosom anak dengan menukarkan beberapa elemen masing-masing kromosom. Parameter pindah silang yang baik ialah 0.6-1.0. (Goldberg 1989). Tahap ini dilakukan one cut point crossover dengan parameter sebesar 0.6.

\section{Mutasi}

Tahap mutasi dilakukan dengan menentukan nilai awal secara acak dengan menggunakan parameter peluang mutasi (Goldberg 1989). Talbi (2009) menganjurkan mutasi yang cukup kecil yaitu antara 0.001-0.01. Proses mutasi dilakukan dengan memilih dua gen secara acak kemudian menukar (swap) dua gen yang terpilih dengan parameter mutasi. Mutasi yaitu sebesar 0.001 dikali dengan banyaknya domain variabel yang digunakan.

\section{Kriteria berhenti}

Kriteria berhenti (stopping criteria) ialah membatasi jumlah generasi dengan berdasarkan syarat fungsi fitness (Engelbrecht 2007). Stopping criteria terjadi ketika nilai fitness lebih besar atau sama dengan minimum confidence (Jaiswal dan Dubey 2013). 


\section{Pembangkitan aturan}

Populasi baru yang dihasilkan oleh algoritme genetika dibangkitkan melalui algoritme apriori. Apriori adalah algoritme untuk mencari frequent itemset dengan menggunakan teknik association rule (Agrawal dan Srikant 1994).

\section{Penambangan aturan asosiasi}

Penambangan aturan asosiasi merupakan implikasi dari bentuk $A$ ke $B$, di mana $A$ dan $B$ adalah 2 himpunan itemset (Han et al.2012). Aturan asosiasi bekerja pada dataset. Rumus support diberikan dalam persamaan 2 (Han et al. 2012):

$$
\operatorname{Support}(A \Rightarrow B)=\frac{\operatorname{count}(A \cup B)}{D}
$$

Rumus confidence diberikan dalam persamaan 3 (Han et al. 2012):

$$
\text { Confidence }(A \Rightarrow B)=\frac{\operatorname{count}(A \cup B)}{\operatorname{count}(A)}
$$

dengan,

A : Antecendent aturan (bagian jika),

$B:$ Consequent aturan (bagian maka),

$D$ : Dataset (transaction)

\section{Klasifikasi asosiatif (Associative Classification)}

Klasifikasi asosiatif merupakan penemuan aturan asosiasi yang berupa aturan jika-maka di mana yang terdapat dalam set aturan seperti $\mathrm{X}=>\mathrm{Y}, \mathrm{Y}$ dijadikan sebagai atribut kelas (label kelas) (Balaji dan Rao 2013).

\section{Algoritme CPAR}

CPAR (Classification based on Predictive Association Rule) adalah algoritme yang berawal dari FOIL (First Order Inductive Learner) yang menggunakan algoritme greedy dalam membangkitkan aturan. Oleh Yin dan Han ( 2003) parameter Total Weight Threshold $(\mathrm{TWT})=0.05$, minimum gain $=0.7$, dan decay factor $=2 / 3$. Formula untuk TWT dihitung dengan persamaan 4 berikut (Herwanto dan Arymurthy (2010); Yin dan Han 2003):

$$
\text { TWT=Bobot sampel positif/bobot sampel negatif } * 0.05
$$

FOIL Gain digunakan untuk mengukur informasi dari penambahan literal ke current rule. Pada persamaan 5 Gain dihitung dengan formula (Yin dan Han 2003):

dengan,

$$
\operatorname{Gain}(p)=\left|P^{*}\right|\left[\log \frac{\left|P^{*}\right|}{\left|P^{*}\right|+\left|N^{*}\right|}-\log \frac{|P|}{|P|+|N|}\right]
$$

$|P|$ : banyaknya objek yang mengandung sampel positif

$|N|$ : banyaknya objek yang mengandung sampel negatif yang memenuhi set aturan

$\left|P^{*}\right|$ : jumlah sampel yang mengandung sampel positif

$\left|N^{*}\right|$ : jumlah sampel yang mengandung sampel negatif yang memenuhi set aturan baru.

Formula untuk LGT dihitung dengan persamaan 6 berikut (Yin dan Han 2003):

$$
\text { LGT }(\text { Local Gain Threshold })=\text { Gain terbesar * Gain silmilarity Ratio }(\%)
$$

Laplace accuracy (LA) yaitu evaluasi aturan untuk memprediksi dan mengetahui kekuatan dari suatu aturan (Yin dan Han 2003). Formula untuk laplace akurasi (LA) dihitung dengan persamaan (7) berikut (Yin dan Han 2003): 
dengan,

$$
\text { laplace akurasi }(\mathrm{LA})=\left(n_{c}+1\right) /\left(n_{t o t}+k\right)
$$

$k$ : jumlah kelas

$n_{\text {tot }}:$ jumlah total aturan dari set aturan yang terpilih

$n_{c}:$ jumlah aturan terpilih yang diprediksi

\section{HASIL DAN PEMBAHASAN}

\section{Optimasi menggunakan Algoritme Genetika}

Optimasi menggunakan algoritme genetika dimulai dengan membangkitkan populasi awal secara acak. Populasi awal yaitu sebanyak 1080 record aturan.

\section{Pengujian Hasil Optimasi}

Berdasarkan hasil pengujian bahwa aturan dapat dikurangi. Pada Tabel 2 diperoleh jumlah aturan yang memiliki rata-rata nilai fitness paling tinggi. Nilai fitness diperoleh dari nilai support dan nilai confidence. Dapat dilihat pada Tabel 2. Jumlah aturan asosiasi dan hasil ratarata nilai fitness dari proses algoritme genetika.

\begin{tabular}{|c|c|c|c|c|c|}
\hline \multirow{2}{*}{ Generasi } & \multicolumn{2}{|c|}{ Terdapat titik panas } & \multicolumn{2}{|c|}{ Tidak terdapat titik panas } & \multirow{2}{*}{ Jumlah rule } \\
\hline & Record & Fitness & Record & Fitness & \\
\hline 50 & 38 & 0.827 & 70 & 0.877 & 108 \\
\hline 100 & 36 & 0.824 & 76 & 0.851 & 112 \\
\hline 150 & 40 & 0.831 & 78 & 0.872 & 118 \\
\hline 200 & 42 & 0.831 & 74 & 0.832 & 116 \\
\hline 300 & 44 & 0.833 & 77 & 0.873 & 121 \\
\hline
\end{tabular}

Aturan yang mempunyai kualitas yang tinggi dapat digunakan untuk memprediksi data (Yin dan Han 2003). Pada Tabel 2 memperlihatkan bahwa pada tiap generasi diperoleh nilai fitness yang tertinggi terdapat titik panas yaitu pada generasi ke-300 dengan rataan nilai fitness sebesar 0.833 . Sedangkan nilai fitness yang tertinggi tidak terdapat titik panas yaitu pada generasi ke-50 dengan rataan nilai fitness sebesar 0.877. Pada Gambar 3 diperoleh grafik garis hasil fitness yang terdapat titik panas dan hasil fitness yang tidak terdapat titik panas.

Grafik garis untuk fitness yang terdapat titik panas pada Gambar 3 memperlihatkan bahwa nilai fitness yang memenuhi syarat kriteria untuk masing-masing aturan ditemukan pada aturan dengan kode RY1,RY2,RY3,RY4,dan R58 dengan rentang nilai fitness sebesar 0.8 hingga 0.9. Grafik garis untuk hasil fitness yang tidak terdapat titik panas pada Gambar 3 memperlihatkan bahwa nilai fitness yang memenuhi syarat kriteria untuk masing-masing aturan ditemukan pada aturan dengan kode $\mathrm{RN} 1, \mathrm{RN} 2, \mathrm{RN} 3, \mathrm{RN} 4$,dan RN5 dengan rentang nilai fitness 0.8 hingga 0.9.Aturan ini dinyatakan aturan yang berkualitas karena memenuhi syarat kriteria.
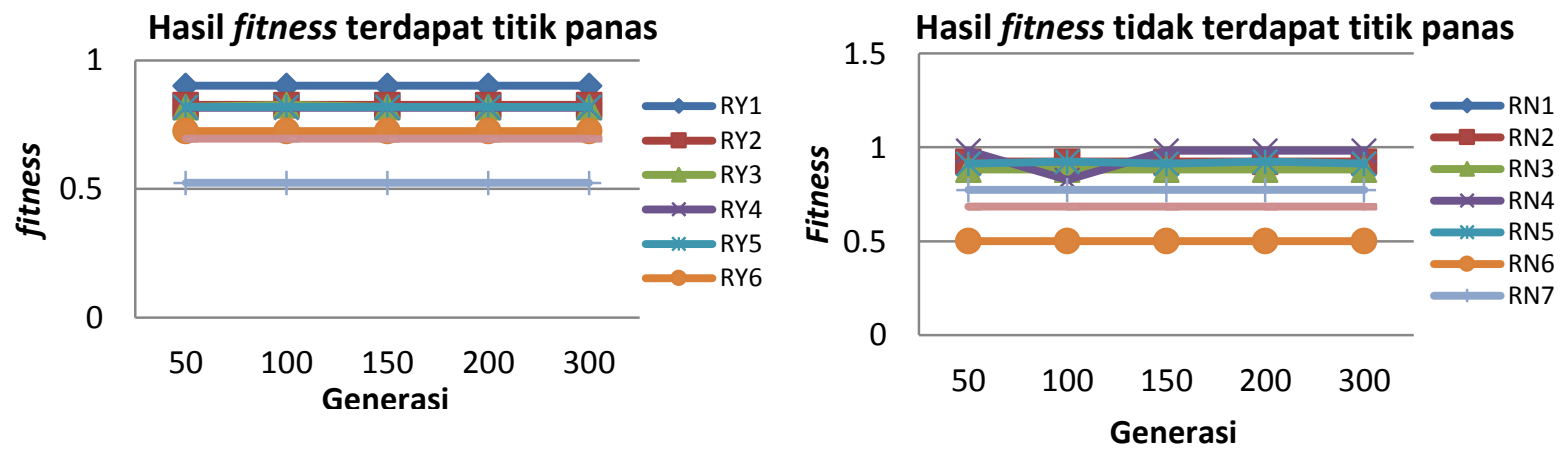

Gambar 3 Hasil fitness terdapat titik panas dan hasil fitness tidak terdapat titik panas 
Keterangan :

$R Y 1=$ precipitation $>=3 \mathrm{~mm} /$ day $\Rightarrow$ hotspot_occurence $=$ Yes

$R Y 2=$ precipitation $>=3 \mathrm{~mm} /$ day dan school $<=0.1$

$=>$ hotspot_occurence $=$ Yes

$R Y 3=$ precipitation $>=3 \mathrm{~mm} /$ daydanscreen_temp $(297 \mathrm{~K} ; 298 \mathrm{~K}$

$=>$ hotspot_occurence $=$ Yes

$R Y 4=$ school $<=0.1=>$ hotspot_occurence $=$ Yes

$R Y 5=$ screen temp $(297 K ; 298 K)=>$ hotspot occurence $=$ Yes

$R Y 6=$ population $=<=50$ dan screen_temp $(297 K ; 298 K)$

$=>$ hotspot occurence $=$ Yes

$R Y 7=$ precipitation $>=3 \mathrm{~mm} /$ daydan

peatland_depth $=n o n \_p e a t l a n d=>$ hotspot_occurence $=Y e s$

$R Y 8=$ screen_temp $(297 K ; 298 K)$ dan

school $<=0 . \overline{1}=>$ hotspot_occurence $=$ Yes

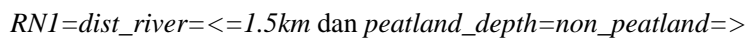
hotspot_occurence $=$ No

$R N 2=$ peatland_depth=non_peatland dan

peatland_type $=$ non_peatland $=>$ hotspot_occurence $=N o$

$R N 3=$ population $=<=50$ dan school $<=0.1 \Rightarrow$ hotspot_occurence $=N o$

$R N 4=$ precipitation $>=3 \mathrm{~mm} /$ day dan school $<=0.1$

$=>$ hotspot occurence $=\mathrm{No}$

$R N 5=$ precipitation $>=3 \mathrm{~mm} /$ day dan peatland_type $=$ non_peatland

$=>$ hotspot occurence $=$ No

$R N 6=$ income_source $=$ Trading_restaurant dan

peatland_depth $=$ non_peatland $=>$ hotspot_occurence $=$ No

$R N 7=$ population $=<=50$ dan peatland_depth $=n o n \_$peatland

$=>$ hotspot_occurence $=\mathrm{No}$

$R N 8=$ precipitation $>=3 \mathrm{~mm} /$ daydan peatland_type $=$ non_peatland

$=>$ hotspot_occurence $=\mathrm{No}$

Berikut Tabel 3 contoh 2 record aturan asosiasi yang terdapat variabel titik panas dan contoh 2 record tidak terdapat variabel titik panas pada tiap generasi.

Tabel 3 Aturan asosiasi tiap generasi

\begin{tabular}{|c|c|c|}
\hline Generasi & Aturan asosiasi & Fitness \\
\hline \multirow{4}{*}{50} & precipitation $>=3 \mathrm{~mm} /$ day $=>$ hotspot_occurence $=$ Yes & 0.901 \\
\hline & screen_temp $(297 K ; 298 K)=>$ hotspot_occurence $=$ Yes & 0.818 \\
\hline & peatland_depth $=n o n \_p e a t l a n d$ dan peatland_type $=n o n \_p e a t l a n d=>$ hotspot_occurence $=N o$ & 0.924 \\
\hline & dist_river $=<=1.5 \mathrm{~km}$ dan peatland_depth $=$ non_peatland $=>$ hotspot_occurence $=$ No & 0.887 \\
\hline \multirow{4}{*}{100} & precipitation $>=3 \mathrm{~mm} /$ day $=>$ hotspot_occurence $=$ Yes & 0.901 \\
\hline & school $<=0.1$ hotspot_occurence $=$ Yes & 0.816 \\
\hline & peatland_depth $=n o n \_p e a t l a n d$ dan peatland_type $=n o n \_p e a t l a n d=>$ hotspot_occurence $=$ No & 0.924 \\
\hline & precipitation $>=3 \mathrm{~mm} /$ day, school $<=0.1$ hotspot_occurence $=$ No & 0.882 \\
\hline \multirow{4}{*}{150} & precipitation $>=3 \mathrm{~mm} /$ day dan school $<=0.1=>$ hotspot_occurence $=$ Yes & 0.826 \\
\hline & precipitation $>=3 \mathrm{~mm} /$ day danscreen_temp $(297 \mathrm{~K} ; 298 \mathrm{~K})=>$ hotspot_occurence $=$ Yes & 0.818 \\
\hline & peatland_depth $=n o n \_p e a t l a n d$ dan peatland_type $=n o n \_p e a t l a n d=>$ hotspot_occurence $=N o$ & 0.924 \\
\hline & precipitation $>=3 \mathrm{~mm} /$ day dan peatland_type $=$ non_peatland $=>$ hotspot_occurence $=N o$ & 0.913 \\
\hline \multirow{4}{*}{200} & precipitation $>=3 \mathrm{~mm} /$ day hotspot_occurence $=$ Yes & 0.901 \\
\hline & screen_temp $(297 K ; 298 K)=>$ hotspot_occurence $=$ Yes & 0.818 \\
\hline & peatland_depth $=n o n \_p e a t l a n d$ dan peatland_type $=n o n \_p e a t l a n d=>$ hotspot_occurence $=N o$ & 0.924 \\
\hline & precipitation $>=3 \mathrm{~mm} /$ day dan peatland_type $=$ non_peatland $=>$ hotspot_occurence $=$ No & 0.924 \\
\hline \multirow{4}{*}{300} & precipitation $>=3 \mathrm{~mm} /$ day dan school $<=0.1=>$ hotspot_occurence $=$ Yes & 0.826 \\
\hline & screen_temp $(297 K ; 298 K)=>$ hotspot_occurence $=$ Yes & 0.818 \\
\hline & precipitation $>=3 \mathrm{~mm} /$ day danpeatland_type $=$ non_peatlan $=>$ hotspot_occurence $=N o$ & 0.913 \\
\hline & population $=<=50$ dan school $<=0.1=>$ hotspot_occurence $=$ No & 0.882 \\
\hline
\end{tabular}

Hasil fitness dari tiap generasi yang terdapat titik panas dan yang tidak terdapat titik panas menghasilkan sejumlah aturan di mana diperlihatkan pada Gambar 4.
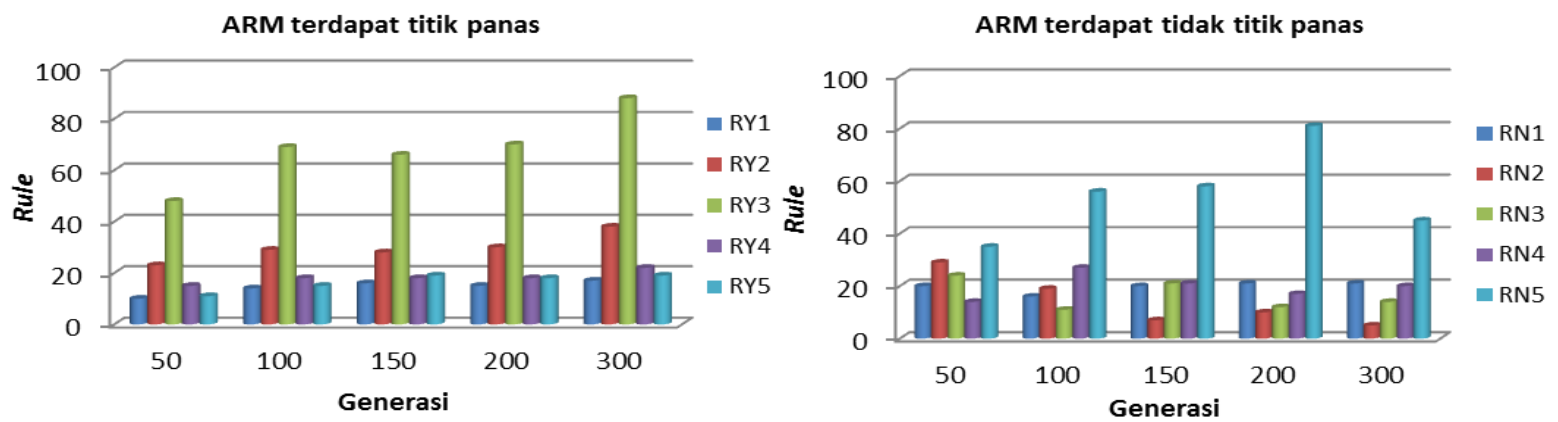

Gambar 4 ARM terdapat titik panas dan ARM tidak terdapat titik panas

Gambar 4 memperlihatkan diperoleh aturan yang terdapat titik panas yang sering muncul yaitu aturan dengan kode RY3, yang menjelaskan jika precipitation $>=3 \mathrm{~mm} /$ day dan screen_temp $(297 K ; 298 K)$ maka hotspot_occurence $=$ Yes. Aturan yang tidak terdapat titik panas 
yang sering muncul adalah aturan dengan kode RN5, yang menjelaskan jika precipitation $>=3 \mathrm{~mm} /$ day dan peatland_type $=$ non_peatland maka hotspot_occurence $=$ No.

\section{Klasifikasi kemunculan titik panas menggunakan algoritme CPAR}

Aturan yang telah diperoleh diklasifikasi untuk sampel data. Pelatihan sampel data dilakukan sebesar $60 \%$ untuk data latih dan $40 \%$ data uji. Data latih dan data uji memuat informasi tentang jarak ke pusat kota terdekat, jarak ke jalan terdekat, jarak ke sungai terdekat, sumber pendapatan, tutupan lahan, kerapatan populasi, curah hujan, sekolah, suhu, kecepatan angin, tipe lahan gambut, kedalaman lahan gambut, kemunculan titik panas. Tabel 4 menunjukkan pembagian sampel data dari tiap generasi.

Tabel 4 Pembagian sampel data dari tiap generasi

\begin{tabular}{cccc}
\hline Generasi & Jumlah Aturan & Data latih & Data uji \\
\hline 50 & 108 & 65 & 43 \\
150 & 118 & 72 & 47 \\
300 & 121 & 73 & 48 \\
\hline
\end{tabular}

Pembagian sampel positif dan sampel negatif dilakukan terhadap data latih yang terdapat pada generasi 50, 150, dan 300. Berikut Tabel 5 jumlah sampel data latih dari tiap generasi.

Tabel 5 Jumlah sampel data latih dari tiap generasi

\begin{tabular}{cccc}
\hline Generasi & Jumlah data latih & Sampel Positif & Sampel negatif \\
\hline 50 & 65 & 28 & 37 \\
150 & 72 & 28 & 44 \\
300 & 73 & 29 & 44 \\
\hline
\end{tabular}

Himpunan aturan terdiri dari 2 label kelas yaitu kelas positif dengan keterangan 'hotspot_occurence=Yes' (terdapat titik panas) dan kelas negatif dengan keterangan 'hotspot_occurence $=N o$ ' (tidak terdapat titik panas). Setiap record diberikan bobot $=1$. Bobot total diproses secara terus menerus sampai bobot total lebih kecil dari TWT. TWT dihitung berdasarkan formula pada persamaan 4. Tabel 6 menunjukkan TWT untuk setiap generasi.

Tabel 6 Total Weight Threshold (TWT) untuk setiap generasi

\begin{tabular}{ccccc}
\hline \multirow{2}{*}{ Generasi } & $\begin{array}{c}\text { Bobot total positif } \\
(\text { record })\end{array}$ & $\begin{array}{c}\text { Bobot total negatif } \\
\text { (record })\end{array}$ & Bobot total sampel positif & Bobot total sampel negatif \\
\cline { 4 - 5 } & 28 & 37 & 1.40 & 1.85 \\
150 & 28 & 44 & 1.40 & 2.20 \\
300 & 29 & 44 & 1.45 & 2.20 \\
\hline
\end{tabular}

\section{Pembentukan Gain}

Atribut yang terpilih ialah atribut yang menghasilkan Gain terbesar (Best Gain) dan telah memenuhi syarat LGT.LGT dihitung berdasarkan persamaan 6.Total bobot untuk setiap kategori yang memiliki Gain terbesar diuji dengan gain similarity ratio sebesar $60 \%$. Tabel 7 Gain terbesar untuk sampel positif dan sampel negatif dengan LGT (bobot=1) setiap generasi.

Tabel 7 Hasil Gain terbesar dengan LGT (bobot=1) untuk setiap generasi

\begin{tabular}{|c|c|c|c|c|}
\hline Sampel & Generasi & Keterangan atribut & Gain terbesar & LGT \\
\hline \multirow{8}{*}{ Positif } & \multirow{3}{*}{50} & Screen_temp $(297 K ; 298 K)$ & 3.84 & \multirow{3}{*}{2.30} \\
\hline & & Precipitation $>=3 \mathrm{~mm} /$ day & 2.97 & \\
\hline & & Population $<=50$ & 2.73 & \\
\hline & \multirow{2}{*}{150} & Precipitation $>=3 \mathrm{~mm} /$ day & 5.52 & \multirow{2}{*}{3.31} \\
\hline & & Screen_temp $(297 K ; 298 K)$ & 4.13 & \\
\hline & \multirow{3}{*}{300} & Precipitation $>=3 \mathrm{~mm} /$ day & 4.56 & \multirow{3}{*}{2.73} \\
\hline & & Wind_speed $(1 \mathrm{~m} / \mathrm{s} ; 2 \mathrm{~m} / \mathrm{s})$ & 3.81 & \\
\hline & & School $<=0.1$ & 3.71 & \\
\hline
\end{tabular}




\begin{tabular}{|c|c|c|c|c|}
\hline Sampel & Generasi & Keterangan atribut & Gain terbesar & LGT \\
\hline \multirow{8}{*}{ Negatif } & \multirow{3}{*}{50} & Screen_temp $(297 K ; 298 K)$ & 3.84 & \multirow{3}{*}{2.30} \\
\hline & & Precipitation $>=3 \mathrm{~mm} /$ day & 2.97 & \\
\hline & & Population $<=50$ & 2.73 & \\
\hline & \multirow{2}{*}{150} & Precipitation $>=3 \mathrm{~mm} /$ day & 5.52 & \multirow{2}{*}{3.31} \\
\hline & & Screen_temp $(297 K ; 298 K)$ & 4.13 & \\
\hline & \multirow{3}{*}{300} & Precipitation $>=3 \mathrm{~mm} / \mathrm{day}$ & 4.56 & \multirow{3}{*}{2.73} \\
\hline & & Wind_speed $(1 \mathrm{~m} / \mathrm{s} ; 2 \mathrm{~m} / \mathrm{s})$ & 3.81 & \\
\hline & & School $<=0.1$ & 3.71 & \\
\hline
\end{tabular}

Tabel 7 memperlihatkan hasil Gain terbesar dari setiap sampel positif dan sampel negatif menghasilkan nilai yang sama. Dengan demikian berdasarkan Tabel 7 menjelaskan bahwa atribut yang memiliki Gain terbesar dari LGT pada generasi 50 adalah atribut Screen_temp $(297 K ; 298 K)$ dengan Gain sebesar 3.84. Generasi 150 adalah atribut Precipitation $>=3 \mathrm{~mm} /$ day dengan Gain sebesar 5.52. Untuk generasi 300 adalah atribut Precipitation $>=3 \mathrm{~mm} /$ day dengan Gain sebesar 4.56. Selanjutnya bobot yang terdapat pada sampel positif dan negatif direvisi menggunakan decay factor. Apabila setiap bobot masih lebih besar dari total bobot (TWT) maka setiap atribut diturunkan hingga lebih kecil dari total bobot. Seluruh total bobot pada setiap sampel positif dan sampel negatif dihitung berdasarkan persamaan 4. Kemudian menghitung Gain berdasarkan formula pada persamaan 5. Tahap ini secara terus menerus dilakukan hingga seluruh nilai Gain yang diperoleh tersebut lebih kecil dari global minimum threshold. Tabel 8 hasil Gain terbesar dengan LGT (bobot=0.66).

Tabel 8 Hasil Gain terbesar dengan LGT (bobot=0.66) untuk setiap generasi

\begin{tabular}{|c|c|c|c|c|}
\hline Sampel & Generasi & Keterangan atribut & Gain terbesar & LGT \\
\hline \multirow{5}{*}{ Positif } & \multirow{3}{*}{50} & Screen_temp $(297 K ; 298 K)$ & 1.21 & \multirow[b]{2}{*}{0.72} \\
\hline & & Population $<=50$ & 1 & \\
\hline & & Wind_speed $\left(1 \mathrm{~m} \mathrm{~s}^{-1} ; 2 \mathrm{~m} \mathrm{~s}^{-1}\right)$ & 0.84 & \multirow[b]{2}{*}{0.96} \\
\hline & 150 & Screen_temp $(297 K ; 298 K)$ & 1.46 & \\
\hline & 300 & $\begin{array}{l}\text { Wind_speed }\left(1 \mathrm{~m} \mathrm{~s}^{-1} ; 2 \mathrm{~m} \mathrm{~s}^{-1}\right) \\
\text { School }<=0.1\end{array}$ & $\begin{array}{l}\mathbf{2 . 0 3} \\
1.35\end{array}$ & 0.81 \\
\hline \multirow{5}{*}{ Negatif } & 50 & $\begin{array}{l}\text { Precipitation }>=3 \mathrm{~mm} / \text { day } \\
\text { Population }<=50\end{array}$ & $\begin{array}{l}\mathbf{5 . 1 8} \\
3.65\end{array}$ & 3.18 \\
\hline & 150 & Precipitation $>=3 \mathrm{~mm} /$ day & 9.62 & 5.77 \\
\hline & \multirow{3}{*}{300} & Precipitation $>=3 \mathrm{~mm} /$ day & 4.56 & \multirow{3}{*}{2.73} \\
\hline & & Wind_speed $\left(1 \mathrm{~m} \mathrm{~s}^{-1} ; 2 \mathrm{~m} \mathrm{~s}^{-1}\right)$ & 3.81 & \\
\hline & & School $<=0.1$ & 3.71 & \\
\hline
\end{tabular}

Pada Tabel 8 menunjukkan bahwa Gain yang diperoleh untuk sampel positif dan sampel negatif pada setiap generasi masih lebih besar dari global minimum yaitu 0.7 , sehingga setiap atribut direvisi kembali dengan bobot sebesar 0.33. Tabel 9 hasil Gain terbesar dengan LGT.

Tabel 9 Hasil Gain terbesar dengan LGT (bobot=0.33)

\begin{tabular}{cclcc}
\hline Sampel & \multirow{2}{*}{ Generasi } & \multicolumn{1}{c}{ Keterangan atribut } & Gain terbesar & LGT \\
\hline \multirow{2}{*}{ Positif } & 50 & Wind_speed $(1 \mathrm{~m} / \mathrm{s} ; 2 \mathrm{~m} / \mathrm{s})$ & $\mathbf{0 . 5 5}$ & 0.33 \\
& 150 & Screen_temp $(297 \mathrm{~K} ; 298 \mathrm{~K})$ & $\mathbf{1 . 4 6}$ & 8.70 \\
\hline \multirow{5}{*}{ Negatif } & \multirow{5}{*}{50} & Precipitation $>=3 \mathrm{~mm} /$ day & $\mathbf{7 . 7 4}$ & \\
& & Screen_temp $(297 \mathrm{~K} ; 298 \mathrm{~K})$ & 7.16 & 4.64 \\
& \multirow{2}{*}{ Population $<=50$} & 4.68 & \\
& 300 & Precipitation $>=3 \mathrm{~mm} /$ day & $\mathbf{1 4 . 5 0}$ & 8.70 \\
& Precipitation $>=3 \mathrm{~mm} /$ day & $\mathbf{1 3 . 7 8}$ & 8.26 \\
\hline
\end{tabular}

Tabel 9 memperlihatkan bahwa untuk sampel positif pada generasi ke 50 ditemukan atribut yang berisi Population $<=50$ dengan Gain sebesar 0.55 yang berarti bahwa nilai Gain yang diperoleh lebih kecil dari global minimum sehingga proses dihentikan. Pada generasi 150 
untuk sampel positif menghasilkan Gain yang lebih besar dari global minimum sehingga direvisi kembali dengan bobot sebesar 0.11. Pada generasi 300 untuk sampel positif tidak ditulis karena Gain dihasilkan kurang dari global minimum sehingga proses revisi dihentikan. Pada Tabel 9 memperlihatkan bahwa Gain yang dihasilkan pada setiap generasi masih lebih besar dari global minimum sehingga direvisi kembali dengan bobot sebesar 0.11. Pada akhir proses semua aturan dihitung menggunakan formula laplace akurasi (LA) pada persamaan 7. Tabel 10 hasil laplace akurasi setiap aturan dengan Gain similarity ratio sebesar $60 \%$.

Tabel 10 Aturan dan hasil laplace akurasi (LA) dengan Gain similarity ratio 60\%

\begin{tabular}{|c|c|c|}
\hline Generasi & Aturan & L.A \\
\hline \multirow[t]{4}{*}{50} & If Population $<=50$ Then hotspot_occurence $=$ Yes & 0.38 \\
\hline & If Precipitation $>=3 \mathrm{~mm} /$ day dan Screen_temp $(297 \mathrm{~K} ; 298 \mathrm{~K})$ Then hotspot_occurence $=$ Yes & 0.76 \\
\hline & If Population $<=50$ Then hotspot_occurence $=\mathrm{No}$ & 0.61 \\
\hline & If Precipitation $>=3 \mathrm{~mm} /$ day dan $\bar{S}$ creen_temp $(297 \mathrm{~K} ; 298 \mathrm{~K})$ Then hotspot_occurence $=$ No & 0.21 \\
\hline \multirow[t]{4}{*}{150} & If Precipitation $>=3 \mathrm{~mm} /$ day Then hotspot_occurence $=$ Yes & 0.52 \\
\hline & If Screen_temp $(297 K ; 298 K)$ Then hotspot_occurence $=$ Yes & 0.57 \\
\hline & If Precipitation $>=3 \mathrm{~mm} /$ day Then hotspot_occurence $=\mathrm{No}$ & 0.47 \\
\hline & If Screen_temp $(297 K ; 298 K)$ Then hotspot_occurence $=N o$ & 0.42 \\
\hline \multirow[t]{4}{*}{300} & If Wind_speed $(1 \mathrm{~m} / \mathrm{s} ; 2 \mathrm{~m} / \mathrm{s})$ Then hotspot_occurence $=$ Yes & 0.70 \\
\hline & If School $<=0.1$ Then hotspot_occurence $=$ Yes & 0.58 \\
\hline & If Wind_speed $(1 \mathrm{~m} / \mathrm{s} ; 2 \mathrm{~m} / \mathrm{s})$ Then hotspot_occurence $=N o$ & 0.30 \\
\hline & If School $<=0.1$ Then hotspot_occurence $=$ No & 0.41 \\
\hline
\end{tabular}

\section{Evaluasi aturan}

Pada Tabel 10 untuk kelas positif memperlihatkan pada generasi 50 diperoleh aturan "If Precipitation $>=3 \mathrm{~mm} /$ day dan Screen_temp $(297 \mathrm{~K} ; 298 \mathrm{~K})$ Then hotspot_occurence $=$ Yes dengan hasil laplace akurasi paling tinggi yaitu sebesar 0.76. Generasi 300 diperoleh aturan If Wind_speed $(1 \mathrm{~m} / \mathrm{s} ; 2 \mathrm{~m} / \mathrm{s})$ Then hotspot_occurence $=$ Yes dengan hasil laplace akurasi paling tinggi yaitu 0.70. Generasi 150 diperoleh aturan If Screen_temp $297 K ; 298 K)$ Then hotspot_occurence $=$ Yes menghasilkan laplace akurasi paling tinggi yaitu 0.57. Berdasarkan aturan yang dihasilkan pada Tabel 3 dan hasil fitness yang diperlihatkan pada Tabel 2 membuktikan bahwa daerah yang terdapat titik panas dari aturan yang ditemukan dapat dinyatakan bahwa daerah tersebut berpotensi memiliki kemungkinan dapat menimbulkan titik panas berdasarkan hasil dari persentase LA yang diperoleh. Hasil persentase menunjukkan bahwa daerah yang memiliki peluang munculnya titik panas yang paling tinggi ditemukan pada daerah yang memiliki curah hujan lebih besar dari atau sama dengan $3 \mathrm{~mm}$ per hari dengan temperatur pada interval 297 Kelvin hingga 298 Kelvin dengan LA sebesar 76\%.

\section{SIMPULAN}

Optimasi terhadap aturan asosiasi multidimensi dapat diterapkan dengan menggunakan algoritme genetika. Melalui algoritme genetika jumlah aturan yang dihasilkan dapat dikurangi yaitu sebanyak 121 hingga 108 aturan asosiasi. Rata-rata nilai fitness yang diperoleh pada tiap generasi yaitu sebesar 0.8 hingga 0.9. Hasil klasifikasi menunjukkan bahwa daerah yang berpotensi timbulnya titik panas yang terdapat pada generasi ke-50 ditemukan pada daerah yang memiliki curah hujan lebih besar dari atau sama dengan $3 \mathrm{~mm}$ per hari dan yang memiliki temperatur pada interval 297 Kelvin hingga 298 Kelvin dengan laplace akurasi sebesar 0.76. Generasi 150 ditemukan daerah yang memiliki temperatur yaitu pada interval 297 Kelvin hingga 298 Kelvin dengan laplace akurasi sebesar 0.57. Generasi 300 ditemukan pada daerah yang memiliki kecepatan angin yaitu pada interval $1 \mathrm{~m} \mathrm{~s}^{-1}$ hingga $2 \mathrm{~m} \mathrm{~s}^{-1}$ dengan laplace akurasi sebesar 0.70 .

\section{DAFTAR PUSTAKA}

Agrawal R, Srikant R. 1994. Fast algorithms for mining association rules, Proceedings of the VLDB Conference. 487-489. 
Balaji BV, Rao VV. 2013. Improved classification based association rule mining, International Journal of Advanced Research in Computer and Coomunication Engineering. 2(5):22112221.

Du F, Rao N, Guo J, Yuan Z, Wang R. 2009. Mining gene network by combined association rules and genetic algorithm, IEEE Journal. 581-585.

Engelbrecht AP. 2007. Computational Intelligence. Second Edition. University of Pretoria.

Ghosh A., Nath B. 2004. Elsevier. 123-133.

Golberg DE. 1989. Genetic Algorithms in Search, Optimization \& Machine Learning. Boston (US): Addison-Wesley.

Gupta MK, Sikka G. 2013. Association rules extraction using multi-objective feature of genetic algorithm, Proceedings of the World Congress on Engineering and Computer Science WCECS 2013.Vol.2

Han J., Kamber M., Pei J. 2012. Data Mining: Concepts and Techniques. San Francisco,(US):Morgan-Kauffman Publisher.

Herwanto, Arymurthy AM. 2010. Penerapan sistem data mining untuk diagnosis penyakit kanker payudara menggunakan classification based on association algorithm. JUTI .8(2).

Hsu P. L., Lai R., Chiu C. C., Hsu C. I. 2003. The hybrid of association rule algorithms and genetic algorithms for tree induction: an example of predicting the student course performance. Expert System with Application. Journal elsevier. Pergamon.51-62.

Indira K., Kanmani S. 2012. Performance analysis of genetic algorithm for mining association rules. International Journal of Computer Science(IJCSI). 9(1):368-376.

Jaiswal A, Dubey G. 2013.Identifying best association rules and their optimization using genetic algorithm.International Journal of Emerging Science and Engineering. 1(7).

Nugroho SP. 2014. Kebakaran Hutan, Menimbulkan Kerugian Ekonomi Terparah. [Internet]. [diunduh 2015 Agustus 12]. Tersedia pada: http://www.mongabay.co.id/2014/05/03/kebakaran-hutan-menimbulkan-kerugianekonomi-terparah/.

Prakash RV,Govardan, SarmaSSVN. 2011. Mining frequent itemsets from large data sets using genetic algorithm.IJCA. Warangal, India. 38-43.

Saxena MR, Shrivastava S, Mathur A. 2012. Association rules mining using modified genetic algorithm. International Journal of Scientific Engineering and Technology. 1(4).

Saggar M, Agrawal AK, Lad A. 2004. Optimization of association rule mining using improved genetic algorithms. IEEE Indian Institute of Information Technology. India.

Sitanggang IS. 2013. Spatial multidimensional association rules mining in forest fire data.Journal of Data Analysis and Information Processing. 1:90-96.

Syaufina L. 2008. Kebakaran Hutan dan Lahan di Indonesia:Perilaku Api, Penyebab dan Dampak Kebakaran. Malang (ID): Bayumedia Publishing.

Talbi, EG. 2009.Metaheuristik:From Design To Implemetation,New Jersey :JohnWiley\&Son.

Yin X, Han J. 2003. CPAR: Classification based on predictive association rules. Proceedings of Siam International 